\title{
Optimization of the process parameters
} for reduction of gossypol levels in cottonseed meal by functional recombinant NADPH-cytochrome $\mathrm{P} 450$ reductase and cytochrome P450 CYP9A 12 of Helicoverpa armigera

\author{
Cheng Chen ${ }^{1 \dagger}$, Yan Zhang ${ }^{2 \dagger}$, Wenhui $\mathrm{Pi}^{3}$, Wenting Yang ${ }^{1}$, Cunxi Nie ${ }^{1,4}$, Jing Liang ${ }^{1}$, Xi Ma ${ }^{1,4}$ \\ and Wen-ju Zhang ${ }^{1 *}$ (1)
}

\begin{abstract}
Gossypol is a toxic polyphenolic product that is derived from cotton plants. The toxicity of gossypol has limited the utilization of cottonseed meal (CSM) in the feed industry. The gene, Helicoverpa armigera CYP9A12, is a gossypolinducible cytochrome P450 gene. The objective of our study was to obtain the functional recombinant $\mathrm{H}$. armigera CYP9A12 enzyme in Pichia pastoris and to verify whether this candidate enzyme could decrease gossypol in vitro. Free and total gossypol contents were detected in the enzyme solution and in CSM. The H. armigera CYP9A12 enzyme degraded free concentration of gossypol. After optimization of the single-test and response surface method, free gossypol content could be decreased to $40.91 \mathrm{mg} / \mathrm{kg}$ in CSM by the H. armigera CYP9A12 enzyme when the initial temperature was $35^{\circ} \mathrm{C}$, the enzymatic hydrolysis time lasted $2.5 \mathrm{~h}$, the enzyme addition was $2.5 \mathrm{~mL}$, and the substrate moisture was 39\%.
\end{abstract}

Keywords: Helicoverpa armigera, Cytochrome P450, CYP9A12, Gossypol, Detoxification

\section{Introduction}

The presence of toxic free gossypol in cottonseed meal (CSM) greatly limited its efficient use in animal feed (Matlin and Zhou 1984; Matlin et al. 1988; Yildirimaksoy et al. 2004). The toxicity of gossypol results from two active aldehyde groups, which also have applications in pharmaceutical and therapeutic methods for such diseases as cancer (Dodou 2005). Our previous studies demonstrated that microbial detoxification of CSM can effectively eliminate its toxic effect (Zhang et al. 2006a,

\footnotetext{
*Correspondence: zhangwj1022@sina.com

${ }^{\dagger}$ Cheng Chen and Yan Zhang contributed equally to this work

${ }^{1}$ College of Animal Science and Technology, Shihezi University,

Shihezi 832000, Xinjiang, China

Full list of author information is available at the end of the article
}

b), but the production efficiency was low for a long fermentation period. The hypothesis was that gossypoldegrading enzymes could play a key role during gossypol detoxification. However, studies on the gossypol-degrading enzyme and its functional gene are rare. Therefore, the target enzyme protein could not be obtained from a heterologous translational system based on the functional gene of that microbial enzyme.

The induction of the $H$. armigera $\mathrm{P} 450$ monooxygenase CYP6AE14 and CYP9A12 genes (Mao et al. 2007; Celorio-Mancera et al. 2011; Zhou et al. 2010) were possibly involved in the resistance and metabolism of gossypol (Jia et al. 2008; Kong et al. 2010; Krempl et al. 2016a, b). The expression of $H$. armigera CYP9A12 and CYP9A14 in yeast can detoxify xenobiotics (Yang et al. 2008), but 
metabolism of gossypol was not studied. The growth and development of $H$. armigera larvae was retarded after they were fed dsRNA CYP6AE14 transgenic plants (Mao et al. 2007, 2011). The NADPH-cytochrome P450 reductase (CPR) was essential to help cytochrome $\mathrm{P} 450$ monooxygenase detoxify the substrates and xenobiotics (Guengerich et al. 2009) because the coexpression of house fly NADPH P450 reductase with $H$. armigera CYP6AE14 (Tao et al. 2012) and CYP6AE14 microsomes (Krempl et al. 2016a) resulted in epoxidation activity towards aldrin.

In our previous study, the functionally coexpressed $H$. armigera CYP9A12 and its CPR had been obtained in the Pichia pastoris system. The H. armigera CYP9A12 microsomal protein could significantly decrease gossypol concentration in enzyme solution and accelerate oxidization of the free gossypol intermediate metabolites $\mathrm{G} 1(\mathrm{~m} / \mathrm{z} 265)$ and $\mathrm{G} 2(\mathrm{~m} / \mathrm{z} 293)$ to the final product $\mathrm{G} 0$ $(\mathrm{m} / \mathrm{z} 209)$ and $\mathrm{G0}^{\prime}(\mathrm{m} / \mathrm{z}$ 249) (Chen et al. 2019). In this study the effect of the $H$. armigera CYP9A12 microsomes on gossypol detoxification in vitro and in the CSM was validated. The optimization of the single-factor test and response surface methodology was used to determine the optimal conditions for gossypol-enzymatic detoxification in CSM to be utilized in the feed industry in the future.

\section{Materials and methods}

\section{Construction and expression of the recombinant plasmids} H. armigera CPR-2A-a-factor signal-CYP9A12

The H. armigera CPR (Accession Number: HM347785.1) and CYP9A12 (Accession Number: AY371318.1) were amplified from $H$. armigera midgut cDNA (Chen et al. 2019) by specific primers and then cloned into the pGEM-T easy vector (Promega, Madison, Wisconsin, USA). The 2A sequence from the foot-and-mouth disease virus (FMDV) (Donnelly et al. 2001) was inserted between the CPR and the $\alpha$-factor secretion signal sequences to obtain the functional protein independently. The $C P R$, the $2 A-\alpha$-factor signal, and CYP9A12 fragments were combined with linearized $p P I C Z \alpha A$ vector using Gibson assembly which was described in our previous study in details (Chen et al. 2019).

The constructed plasmid were linearized and subsequently transformed into P. pastoris GS115 competent cells by electroporation. The transformants were selected by Zeocin antibiotic plate. The prepared buffered glycerol-complex medium (BMGY) and buffered methanol-complex medium (BMMY) were used to the yeast growth and induction. The microsomes were isolated by differential centrifugation of the cell homogenate. The separated $H$. armigera monooxygenase and reductase were detected by SDS-PAGE and the $H$. armigera CYP9A12 proteins were specifically detected with an
anti-His-tagged mouse polyclonal antibody (CST, USA) and an eECL Western blotting kit (CW Biotech, Beijing, China) (Chen et al. 2019).

\section{Validation of the H. armigera CYP9A 12 for the detoxification of gossypol from CSM}

A total of $2.5 \mathrm{~mL} \mathrm{H}$. armigera CYP9A12 enzyme (equivalent to $575 \mathrm{U} / \mathrm{mg}$ enzyme activity unit) was added to $50 \mathrm{~g}$ $\mathrm{CSM}$ at an initial temperature of $30{ }^{\circ} \mathrm{C}$, substrate moisture of $50 \%$ and was incubated for $4 \mathrm{~h}$. The conditions of the Candida tropicalis group were fermentation time $48 \mathrm{~h}$, fermentation temperature $30{ }^{\circ} \mathrm{C}$, inoculum volume $5 \%(\mathrm{v} / \mathrm{w})$, substrate moisture content $50 \%$, natural $\mathrm{pH}$, and three replicates per treatment (Zhang et al. 2006a, b). The control group (without any enzyme) was inoculated with the same volume of distilled water. After the reaction was finished, the samples were dried in a vacuum freezer and crushed through 60-mesh screens for detection (Firestone 2003).

CSM or treated CSM (500 mg) was accurately weighed and ultrasonically extracted with $70 \%$ acetone and butanone, respectively, at room temperature for $1 \mathrm{~h}$. The total and free gossypol contents in the CSM were determined using HPLC as described above (Chen et al. 2018).

\section{Optimization of the $H$. armigera CYP9A12 enzymatic hydrolytic conditions for the CSM Single-factor test}

The detoxification conditions of the CSM enzymatic hydrolysis primarily include temperature, time, the amount of enzyme added, and substrate moisture. Use of the proper enzymatic hydrolysis conditions could not only improve the quality of CSM products and save resources but also increase production efficiency. The single-factor design was used to optimize the conditions of the $H$. armigera CYP9A12 enzyme in CSM enzymatic detoxification. The level conditions were based on the single factor test. CSM $(50 \mathrm{~g})$ was weighed into the corresponding number conical bottle. Sterilized water was added according to the ratio of the material to water $(35 \%, 40 \%, 45 \%$ and $50 \%$ ) (Table 1$)$. The enzymatic hydrolytic temperature and time were set based on different levels in the table. The $H$. armigera CYP9A12 enzyme of $0.5 \mathrm{~mL}, 1.5 \mathrm{~mL}, 2.5 \mathrm{~mL}$ and $3.5 \mathrm{~mL}$ were added which represented to $1 \%, 3 \%, 5 \%$ and $7 \%$ of CSM weight, respectively. The $H$. armigera CYP9A12 enzyme activities were $115 \mathrm{U} / \mathrm{mg}, 345 \mathrm{U} / \mathrm{mg}$, and $575 \mathrm{U} / \mathrm{mg}$, respectively. The concentration of the crude enzyme protein was $1.05 \mathrm{mg} / \mathrm{mL}$ and $230 \mathrm{U} / \mathrm{mg}$, respectively. The concentration of the crude enzyme protein was $1.05 \mathrm{mg} / \mathrm{mL}$ and $230 \mathrm{U} /$ mg, respectively (Bradford 1976). The enzymatic hydrolysis of the CSM was sampled after the reaction and dried in a vacuum freezer. Free and total gossypol content was determined by HPLC after crushing, sieving through 60-mesh, 
Table 1 The level table of single test factor

\begin{tabular}{lllll}
\hline Variable & $\begin{array}{l}\text { A } \\
\text { Initial } \\
\text { temperature }{ }^{\circ} \mathbf{C}\end{array}$ & $\begin{array}{l}\text { B } \\
\text { Enzymolysis } \\
\text { time h }\end{array}$ & $\begin{array}{l}\text { C } \\
\text { Enzyme } \\
\text { amount } \\
\mathbf{m L}\end{array}$ & $\begin{array}{l}\text { D } \\
\text { Substrate } \\
\text { moisture \% }\end{array}$ \\
\hline 1 & 25 & 1 & 0.5 & 35 \\
2 & 30 & 2 & 1.5 & 40 \\
3 & 35 & 6 & 2.5 & 45 \\
4 & 40 & 12 & 3.5 & 50 \\
\hline
\end{tabular}

Table 2 Box-Behnken experimental factors and coding levels

\begin{tabular}{lllll}
\hline Code & Variable & \multicolumn{3}{l}{ The coding level } \\
\cline { 3 - 5 } & & $\mathbf{- 1}$ & $\mathbf{0}$ & $\mathbf{1}$ \\
\hline A & Initial temperature ${ }^{\circ} \mathrm{C}$ & 33 & 35 & 37 \\
$\mathrm{~B}$ & Enzymolysis time $\mathrm{h}$ & 1.5 & 2 & 2.5 \\
$\mathrm{C}$ & Enzyme additive amount $\mathrm{mL}$ & 2.25 & 2.5 & 2.75 \\
$\mathrm{D}$ & Substrate moisture \% & 38 & 40 & 42 \\
\hline
\end{tabular}

and supersonic extraction with acetone and butanone. The same treatment was repeated in three replicates.

\section{Box-Behnken experimental design}

The Box-Behnken experimental design is based on the mathematical model:

$$
Y=\beta_{0}+\sum \beta_{i} x_{i}+\sum x_{i} x_{j}+\sum \beta_{i i} x_{i}^{2}
$$

$Y$ is the response value (gossypol content); $\beta_{0}$ is a constant term, $\beta_{i}$ and $\beta_{i i}$ are regression coefficients, and $x_{i}$ and $x_{j}$ are coded variables (temperature, time, enzyme addition and substrate moisture) (Ferreira et al. 2007). The contents of free gossypol in the detoxified CSM was used as the evaluation index in the Box-Behnken design. Each factor in the Box-Behnken design was coded as three levels with $-1,0$, and +1 (Table 2). The quadratic regression fitting was conducted to get the quadratic equation with interactive terms and square terms using the corresponding code. The primary effects and interaction effects of each factor were analyzed. Finally, the optimal value was obtained within a certain level. One-way ANOVA analysis of multiple variables were carried out with the SPSS 17.0.

\section{Results}

Detoxification effect of the $H$. armigera CYP9A12 enzyme in enzyme solution

The $H$. armigera CYP9A12 was obtained as described in our previous study (Chen et al. 2019). To validate the detoxification effect of $H$. armigera CYP9A12 in the enzyme reaction solution, the free and total gossypol contents were determined in the control group (without enzyme), endogenous group, and $H$. armigera CYP9A12 enzyme group, respectively. The results are shown in Table 3 . The total gossypol was significantly decreased by $22.5 \%$ and $14.8 \%$ in comparison with the control group, respectively. The free gossypol content in solution was decreased by $2.5 \%$ and $2.6 \%$ after the addition of $H$. armigera CYP9A12 enzyme and endogenous enzyme, respectively.

Because gossypol is unstable and is easily oxidized, the P450 enzyme co-factor NADPH- $\mathrm{Na}_{4}$ was added to initiate the reaction and stabilize the gossypol. The ability of the $H$. armigera CYP9A12 enzyme to degrade gossypol was defined as the amount of one micromole of gossypol degraded per minute catalyzed by $1 \mathrm{mg}$ of enzyme at

Table 3 Effect of different treatments on gossypol content in cottonseed meal

\begin{tabular}{|c|c|c|c|c|}
\hline \multirow[t]{2}{*}{ Treatment } & \multicolumn{4}{|c|}{ Enzyme reaction solution } \\
\hline & Total gossypol (TG) & Detoxification rate (\%) & Free gossypol (FG) & $\begin{array}{l}\text { Detoxification } \\
\text { rate }(\%)\end{array}$ \\
\hline Control group & $34.25^{\mathrm{a}} \pm 3.35$ & - & $27.53 \pm 2.80$ & - \\
\hline Endogenous group & $29.16^{b} \pm 2.37$ & 14.8 & $26.81 \pm 1.55$ & 2.6 \\
\hline \multirow[t]{3}{*}{ H. armigera CYP9A12 } & $26.53^{b} \pm 1.91$ & 22.5 & $20.59 \pm 2.54$ & 2.5 \\
\hline & \multicolumn{4}{|c|}{ Enzymatic hydrolysis of cottonseed meal } \\
\hline & Total gossypol (TG) & Detoxification rate (\%) & Free gossypol (FG) & $\begin{array}{l}\text { Detoxification } \\
\text { rate }(\%)\end{array}$ \\
\hline Control group & $147.21^{\mathrm{a}} \pm 0.88$ & - & $110.23^{\mathrm{a}} \pm 1.13$ & - \\
\hline Endogenous group & $125.71^{c} \pm 12.6$ & 14.6 & $99.92^{\mathrm{a}} \pm 6.7$ & 9.3 \\
\hline H. armigera CYP9A12 & $69.61^{b} \pm 3.08$ & 52.7 & $33.39^{b} \pm 1.53$ & 69.7 \\
\hline Candida tropicalis & $53^{b} .28 \pm 3.65$ & 63.8 & $42.32^{c} \pm 5.52$ & 61.6 \\
\hline
\end{tabular}


$30{ }^{\circ} \mathrm{C}(\mathrm{pH} 6)$. A unit of enzyme activity was expressed as $\mathrm{U} / \mathrm{mg}$. According to the definition of this enzyme activity, the concentration of $H$. armigera CYP9A12 enzyme protein in the supernatant of cell fragmentation induced by methanol for $72 \mathrm{~h}$ was $1.05 \mathrm{mg} / \mathrm{mL}$, and the enzyme activity was $230 \mathrm{U} / \mathrm{mg}$.

\section{Detoxification effect of $H$. armigera CYP9A12 enzyme on CSM}

To validate the detoxification effect of $H$. armigera CYP9A12 enzyme in CSM, the free and total gossypol contents were determined in the control group, endogenous group, $H$. armigera CYP9A12 enzyme, and $C$. tropicalis group. The results are shown in Table 3 . The free gossypol content in the CSM decreased by $52.7 \%$ and $63.8 \%$ after the addition of $H$. armigera CYP9A12 enzyme and $C$. tropicalis yeast $(p<0.05)$, respectively. Total gossypol significantly decreased by $69.7 \%$ and $61.6 \%$ for $H$. armigera CYP9A12 and $C$. tropicalis, respectively, in comparison to the control group $(p<0.05)$.

\section{Single factor test results of CSM enzymatic hydrolysis and detoxification by the $H$. armigera CYP9A 12 enzyme}

To optimize conditions of the $H$. armigera CYP9A12 enzyme on CSM, four different factors (initial temperature, enzymatic hydrolysis time, enzyme content, and substrate moisture) were planned in accordance with the abscissa, the ordinate free gossypol content for result analysis.

The highest gossypol concentration in the enzymatic hydrolysis time was at $40{ }^{\circ} \mathrm{C}$, and the lowest was observed at $35{ }^{\circ} \mathrm{C}$. The hydrolysis time lasted $12 \mathrm{~h}$, and the gossypol concentration was the highest, while the lowest was observed when the reaction time was $2 \mathrm{~h}$. The highest and lowest contents of free gossypol were observed when the amount of enzyme was 0.5 and $2.5 \mathrm{~mL}$, respectively. When the substrate moisture was $45 \%$, the gossypol content was the highest. When the substrate moisture was $50 \%$, gossypol concentration decreased to the lowest amount. In a single factor analysis test, the optimal condition of the effect of $H$. armigera CYP9A12 enzyme on CSM gossypol degradation was achieved with $2.5 \mathrm{~mL}$ of enzyme. The enzymatic hydrolysis lasted $2 \mathrm{~h}$ at $35^{\circ} \mathrm{C}$, and the substrate moisture was $40 \%$ (Fig. 1) in accordance with the abscissa, the ordinate free gossypol content for concentration curve for result analysis.

\section{Box-Behnken test results of CSM enzymatic hydrolysis and detoxification of $H$. armigera CYP9A 12 enzyme Model establishment and significance test analysis}

Various factors do not exist independently in the process of enzymatic hydrolysis because they interact with each other. The response surface method was used to optimize the $H$. armigera CYP9A12 enzyme application conditions. The Box-Behnken test was designed using Design Expert software to quantify the effectiveness of key factors (initial temperature, enzymatic hydrolysis time, enzyme content, and substrate moisture) and the interactions among them. The free gossypol content was chosen as the response value $Y$ for the purpose of this test. The independent variables, codes, and levels are shown in Table 2. The results obtained from 29 test points are shown in Table 4.

Twenty-nine test points were divided into two categories. One category was a factorial point of 24 points corresponding to the independent variable values in $\mathrm{A}, \mathrm{B}, \mathrm{C}$, and $\mathrm{D}$ constituting a three-dimensional vertex. The others were zero points in the center of the region, which had been repeated five times to estimate the test error. The results have shown the gossypol content of the CSM under the Box-Behnken experimental design (Table 4). The minimum and maximum gossypol contents were 36.54 and $73.18 \mathrm{mg} / \mathrm{mL}$, respectively. The overall average value was $50.67 \mathrm{mg} / \mathrm{mL}$; the overall standard deviation (SD) was 7.27, and the coefficient of variation $(\mathrm{CV})$ was $7.35 \%$ meeting the requirements of the Box-Behnken analysis. The results were analyzed using multivariable regression fitting to obtain the quadratic polynomial regression equation of $Y$ pairs of coded independent variables A, B, C and D.

$$
\begin{aligned}
Y= & 37.74-3.03 \mathrm{~A}-5.40 \mathrm{~B}-0.27 \mathrm{C}-0.83 \mathrm{D} \\
& +1.54 \mathrm{AB}+0.73 \mathrm{AC}+2.10 \mathrm{AD}-1.91 \mathrm{BC}+8.50 \mathrm{BD} \\
& +2.19 \mathrm{CD}+7.32 \mathrm{~A}^{2}+5.24 \mathrm{~B}^{2}+8.41 \mathrm{C}^{2}+10.29 \mathrm{D}^{2}
\end{aligned}
$$

The results showed that the experimental data in Table 4 were statistically significant $(p=0.0411$, $\left.\mathrm{R}^{2}=0.7238\right)$, and the significant factor was the enzymatic hydrolytic time $(\mathrm{B}, p=0.0221)$.

\section{Response surface analysis of gossypol on the effect of the $H$. armigera CYP9A12 enzyme on CSM}

To obtain the range of responses for the four factors studied, two of the variables could be fixed at the central value, and the effects of the other two variables on gossypol content in CSM were analyzed and evaluated based on the response surface diagram and contour plot of the multivariate quadratic equation. The shape of the contours could reflect the intensity of the interaction effect. A circle indicates that the interaction between the two factors is not significant, but an ellipse indicates the interaction is significant.

Results of the response surface graph and contour plot showed that factor B (enzymatic hydrolysis time) had a meaningful effect on gossypol content $(p=0.02)$, and the interaction between factor B and D was also important 

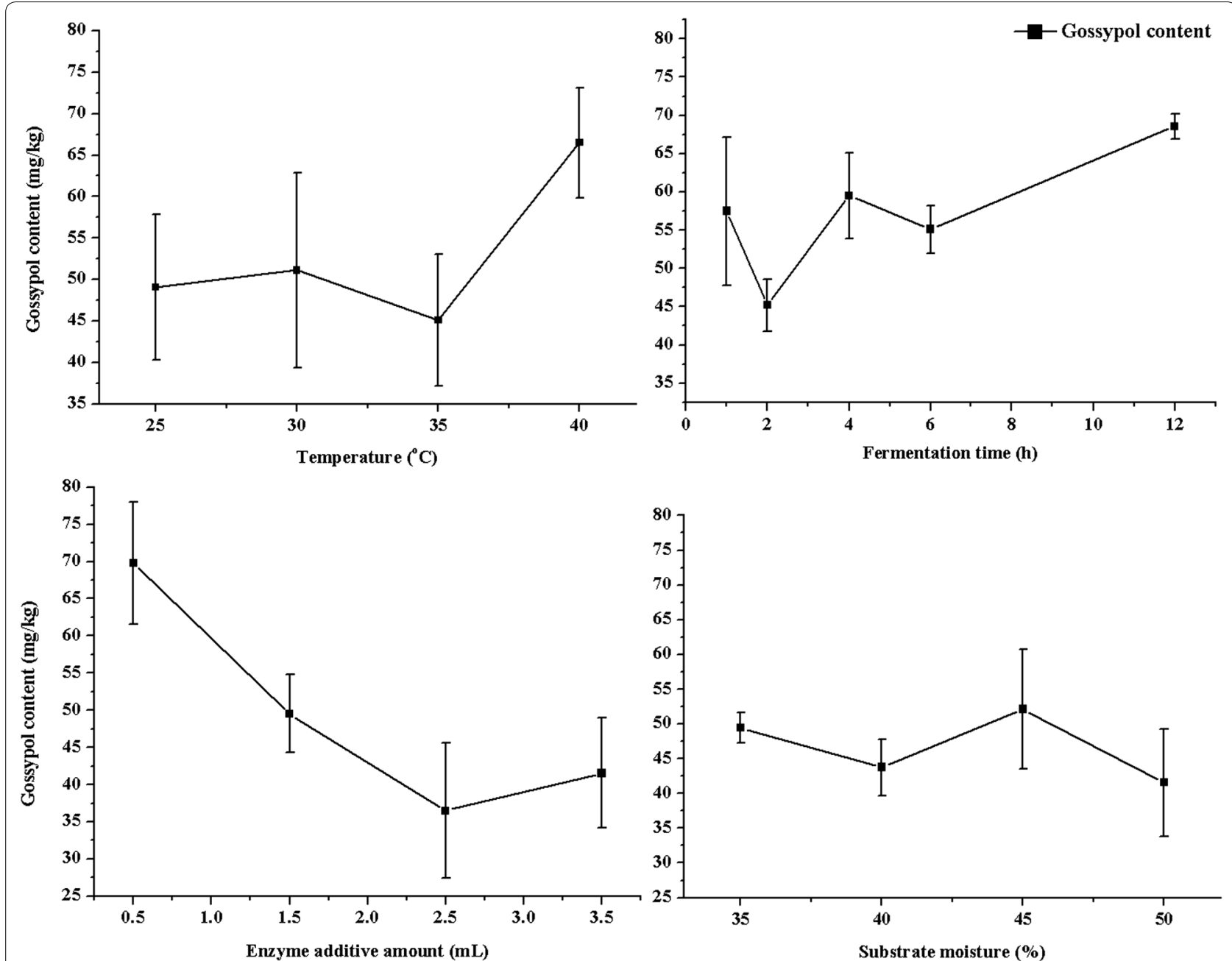

Fig. 1 The single-factor test of the effect on gossypol of cottonseed meal by the H. armigera CYP9A12. The four different factors include initial temperature, enzymatic hydrolysis time, enzyme content, and substrate moisture. In accordance with the abscissa, the ordinate free gossypol content for concentration curve for result analysis. The optimal condition of the effect of $\mathrm{H}$. armigera CYP9A12 enzyme on CSM gossypol degradation was achieved with $2.5 \mathrm{~mL}$ of enzyme. The enzymatic hydrolysis lasted $2 \mathrm{~h}$ at $35^{\circ} \mathrm{C}$, and the substrate moisture was $40 \%$

$(p=0.034)$ (Fig. 2). The interaction between the other factors was not significant difference. The predicted minimum gossypol content was $36.73 \mathrm{mg} / \mathrm{kg}$ under the following conditions: initial temperature $35.44{ }^{\circ} \mathrm{C}$, enzymatic hydrolysis time $2.5 \mathrm{~h}$, enzyme addition $2.55 \mathrm{~mL}$ and substrate moisture $39.23 \%$. The predicted value was higher than the actual minimum value in the BoxBehnken experiment.

To verify the accuracy of the model, three experiments were conducted using the optimal conditions. The minimum gossypol content was $42.34 \mathrm{mg} / \mathrm{kg}, 40.72 \mathrm{mg} / \mathrm{kg}$, and $39.68 \mathrm{mg} / \mathrm{kg}$, with an average of $40.91 \mathrm{mg} / \mathrm{kg}$. The results showed that the model could predict the optimal conditions for the $H$. armigera CYP9A12 enzymatic detoxification. After the optimization of the single factor and the Box-Behnken experimental design, the free gossypol content of the CSM decreased $88.4 \%$ from 352.94 to $40.91 \mathrm{mg} / \mathrm{kg}$.

\section{Discussion}

Gossypol is a natural phenolic compound that is derived from cotton plants. The toxicity of gossypol results from two active aldehyde groups which are toxic to most organisms (Nomeir and Abou-Donia 1985; Eisele 1986; Brocas et al. 1997; Chenoweth et al. 2000). The $H$. armigera CYP6 and CYP9 family genes CYP321A1, CYP9A12, CYP9A14, CYP6AE11, CYP6B6 and CYP6B7 are gossypol-inducible, which probably explains gossypol resistance of the $H$. armigera larvae (Yang et al. 1999; Celorio-Mancera et al. 2011; Mao et al. 2007, 2011; Tao 
Table 4 Box-Behnken design and gossypol content

\begin{tabular}{|c|c|c|c|c|c|}
\hline \multirow[t]{2}{*}{ Treatment } & \multicolumn{4}{|c|}{ Factor } & \multirow{2}{*}{$\begin{array}{l}\text { Result } \\
\text { Y mg/kg } \\
\text { Gossypol } \\
\text { content mg/ } \\
\text { kg }\end{array}$} \\
\hline & A & B & $C$ & D & \\
\hline 1 & 33 & 1.5 & 2.5 & 40 & 65.59 \\
\hline 2 & 37 & 1.5 & 2.5 & 40 & 58.5 \\
\hline 3 & 33 & 2.5 & 2.5 & 40 & 46.07 \\
\hline 4 & 37 & 2.5 & 2.5 & 40 & 45.16 \\
\hline 5 & 35 & 2 & 2.25 & 38 & 63.21 \\
\hline 6 & 35 & 2 & 2.75 & 38 & 47.61 \\
\hline 7 & 35 & 2 & 2.25 & 42 & 67.95 \\
\hline 8 & 35 & 2 & 2.75 & 42 & 58.11 \\
\hline 9 & 33 & 2 & 2.5 & 38 & 61.35 \\
\hline 10 & 37 & 2 & 2.5 & 38 & 50.14 \\
\hline 11 & 33 & 2 & 2.5 & 42 & 48.12 \\
\hline 12 & 37 & 2 & 2.5 & 42 & 48.32 \\
\hline 13 & 35 & 1.5 & 2.25 & 40 & 45.4 \\
\hline 14 & 35 & 2.5 & 2.25 & 40 & 46.88 \\
\hline 15 & 35 & 1.5 & 2.75 & 40 & 51.48 \\
\hline 16 & 35 & 2.5 & 2.75 & 40 & 45.33 \\
\hline 17 & 33 & 2 & 2.25 & 40 & 56.18 \\
\hline 18 & 37 & 2 & 2.25 & 40 & 44.56 \\
\hline 19 & 33 & 2 & 2.75 & 40 & 62.08 \\
\hline 20 & 37 & 2 & 2.75 & 40 & 53.37 \\
\hline 21 & 35 & 1.5 & 2.5 & 38 & 73.18 \\
\hline 22 & 35 & 2.5 & 2.5 & 38 & 42.56 \\
\hline 23 & 35 & 1.5 & 2.5 & 42 & 48.11 \\
\hline 24 & 35 & 2.5 & 2.5 & 42 & 51.48 \\
\hline 25 & 35 & 2 & 2.5 & 40 & 44.11 \\
\hline 26 & 35 & 2 & 2.5 & 40 & 39.22 \\
\hline 27 & 35 & 2 & 2.5 & 40 & 36.94 \\
\hline 28 & 35 & 2 & 2.5 & 40 & 43.87 \\
\hline 29 & 35 & 2 & 2.5 & 40 & 36.54 \\
\hline
\end{tabular}

This table is the experimental results of Box-Behnken design and corresponding schemes. The gossypol content is selected as the response value $Y$. The independent variables $A, B, C$ and $D$ was corresponding to initial temperature, enzymatic hydrolysis time, enzyme content, and substrate moisture are shown in the table

et al. 2012; Zhou et al. 2010, Tian et al. 2017) or Helicoverpa zea larve (Stipanovic et al. 2006). Usually, the effects of the insect P450 enzymes on xenobiotics after expression in E. coli (Andersen et al. 1994; Guzov et al. 1998; Hayashi et al. 2003; Kaewpa et al. 2007; Liu et al. 2012), yeast (Pompon et al. 1996; Dietrich et al. 2005; Mirzaei et al. 2010) or insect $S f 9$ cells (Krempl et al. 2016a, b) are nonfunctional when isolated from insect tissue (Andersen et al. 1994).

The H. armigera CYP6AE14 was solely expressed in Sf9 cells but had no gossypol metabolic activity (Krempl et al. 2016a). However, the CYP6AE14 microsomes (Krempl et al. 2016a) and the coexpression of the NADPH P450 reductase from houseflies with $H$. armigera CYP6AE14 (Tao et al. 2012) had epoxidation activity towards aldrin. Presumably assistance of NADPH-cytochrome P450 reductase (CPR) to donate an electron was required. $H$. armigera CYP9A12 and CYP9A14 enzymes obtained from yeast have the ability to detoxify xenobiotics (Yang et al. 2008), but there have been no further metabolic studies related to gossypol.

After $H$. armigera CYP9A12 or endogenous enzyme treatment, free and total gossypol was extracted with $70 \%$ aqueous acetone and butanone, respectively, and prepared for HPLC analysis. The NADPH- $\mathrm{Na}_{4}$ was added to initiate the P450s enzyme reaction (Yang et al. 2004). Total gossypol content was equal to bound gossypol plus the free gossypol. Bound gossypol would be formed by free gossypol covalently binding to proteins in the reaction. Therefore, the endogenous group was assigned to remove the error. Total gossypol content decreased significantly from 34.25 to 29.16 and $26.53 \mu \mathrm{g} / \mathrm{mL}$ in the endogenous group and the $H$. armigera CYP9A12 group, respectively. In addition, free gossypol concentration decreased significantly from 27.53 to 26.81 and $20.59 \mu \mathrm{g} / \mathrm{mL}$ in the endogenous group and the $H$. armigera CYP9A12 group, respectively (Table 3 ). This value refers to the free gossypol that was metabolized by the $H$. armigera CYP9A12 enzyme rather than bound to the proteins.

Gossypol was characterized into gossypolone, gossypolonic acid, and demethylated gossic acid in pig livers (Abou-Donia and Dieckert 1975). The suggested oxidation pathway of gossypol $(\mathrm{m} / z$ 517) was first the formation of gossypolone $(\mathrm{m} / z$ 545) and subsequently gossypolonic acid $(m / z 577)$, which was cleaved and oxidized to demethylated gossic acid $(\mathrm{m} / z$ 265) (Abou-donia and Dieckert 1974; Liu et al. 2014). Based on our previous study, the gossypol with an ion mass of 517.1910 would be spontaneously degraded to the gossypol metabolites, G1 and G2 with ion masses of 265.0411 and 293.1123. In addition, the two gossypol metabolites G1 and G2 would be degraded by $H$. armigera CYP9A12 enzyme into G0 and G0' with ion masses of 209.0833 and 248.9578, respectively (Chen et al. 2019). Thus, the accumulation products $\mathrm{GO}^{\prime}$ and $\mathrm{G} 0$ were proposed to indirectly accelerate the metabolism of gossypol by the $H$. armigera recombinant CYP9A12 enzyme (Fig. 3).

Currently, the effective method of gossypol detoxification in CSM is microbial solid-state fermentation (Zhong and Wu 1989; Zhang et al. 2006a, b). However, the addition of corn flour, bran and other auxiliary materials and high-pressure sterilization during the drying process would result in the reduction of the free gossypol 

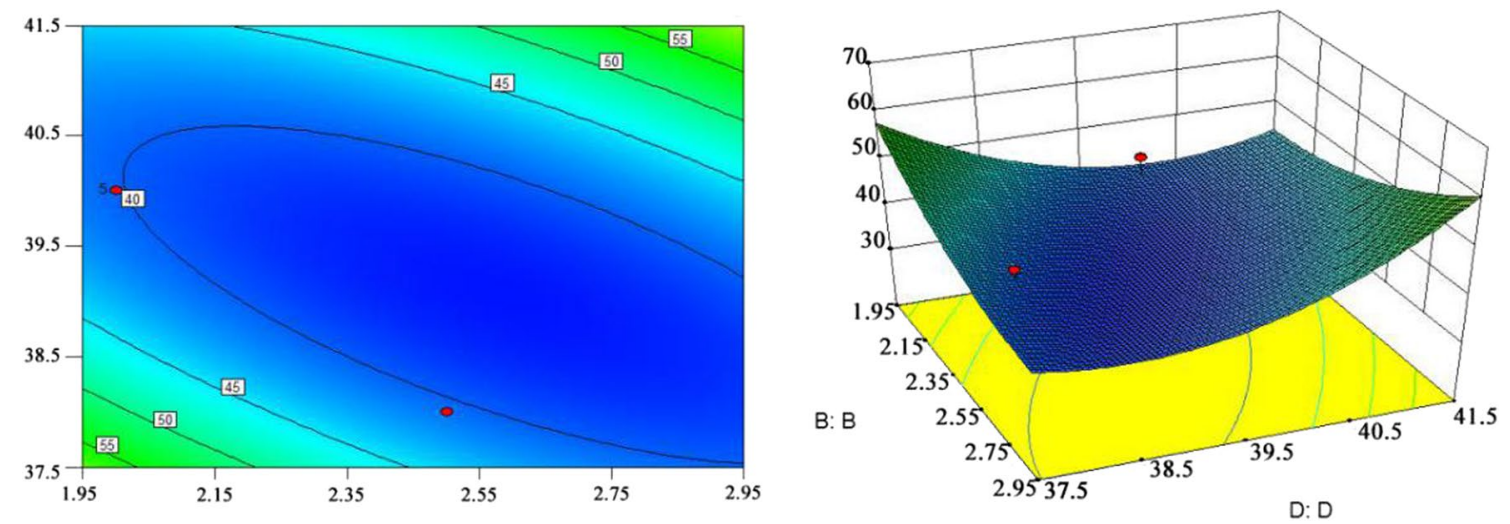

Fig. 2 Contour plots and response surface diagram of the effect of reaction time (B) and cottonseed meal moisture (D) was analyzed on gossypol contents. The shape of contours could reflect the intensity of the interaction effect. The ellipse indicates that the interaction between the effect of reaction time (B) and cottonseed meal moisture (D) on gossypol content is significant

in solid-state processed CSM. The traditional solid-state fermentation of CSM has usually lasted for at least 2 days (Zhang et al. 2006b). It is difficult and costly to avoid the contamination of bacteria caused by excessive fermentation time. If the $H$. armigera recombinant CYP9A12 enzyme could be used in CSM, it could rapidly degrade gossypol content and greatly save time.

To validate the detoxification effect of the $H$. armigera CYP9A12 enzyme in CSM, free and total gossypol contents were determined in the control group, the endogenous group, the $H$. armigera CYP9A12 enzyme, and the C. tropicalis group. Before the experiment, an ultraviolet lamp was used to sterilize the CSM instead of autoclaving it. In addition, the experimental CSM was dried by vacuum freeze drying to avoid thermal influence on the gossypol content in CSM. The decrease of free gossypol in the CSM was degraded by microbial fermentation instead of binding with proteins to form bound gossypol (Wei et al. 2011). The free and total gossypol content in the CSM significantly decreased after the $H$. armigera CYP9A12 reaction and C. tropicalis fermentation (Table 3).

The optimal conditions of the four factors (temperature, time, enzyme addition and substrate moisture) were determined using the single-factor (Fig. 1) and response surface methods, respectively. Because the thermal stability of gossypol was below $40{ }^{\circ} \mathrm{C}$, the temperature range of the $H$. armigera CYP9A12 enzyme detoxification of CSM was selected from 25 to $40{ }^{\circ} \mathrm{C}$. However, in this experiment, the gossypol content in the CSM after processing was the highest when the temperature was $40{ }^{\circ} \mathrm{C}$. We hypothesized that if the CSM in the enzymatic hydrolysis test was not sterilized after autoclaving, the growth of residual bacteria might lead to the increase in free gossypol content. We also found that the free gossypol content in the CSM was higher when the enzymatic hydrolysis temperature was $40^{\circ} \mathrm{C}$ or the enzymatic hydrolysis time had lasted $12 \mathrm{~h}$. A temperature of $37{ }^{\circ} \mathrm{C}$ and growth incubation time of $12 \mathrm{~h}$ are optimal conditions for Bacillus subtilis and E. coli growth, respectively. The optimal degradation time of $H$. armigera CYP9A12 enzyme in vitro was $30 \mathrm{~min}$. Considering the existence of free gossypol in the CSM, the H. armigera CYP9A12 enzyme required full contact with the gossypol to degrade it. Therefore, the enzymatic hydrolysis time was set to $1,2,4,6$, and $12 \mathrm{~h}$, respectively. The optimal enzymatic hydrolysis time for $H$. armigera CYP9A12 enzyme in CSM was $2 \mathrm{~h}$. The coenzyme NADPH-Na ${ }_{4}$ was added to ensure the $H$. armigera CYP9A12 enzyme functioned. The free gossypol concentration in the CSM did not change significantly when the $H$. armigera CYP9A12 enzyme was added between $0.5 \mathrm{~mL}$ and $2.5 \mathrm{~mL}$. The optimal CYP9A12 enzyme addition was determined to be $2.5 \mathrm{~mL}$. When the substrate moisture was $50 \%$, the gossypol level was the lowest, which could effectively increase the contact area between the $H$. armigera CYP9A12 enzyme and the gossypol in the CSM. Low moisture content does not help to decrease the gossypol, and excessive moisture would lead to additional drying and cost.

The $p$ values of the primary and quadratic terms were less than 0.05 in the Box-Behnken response surface analysis, of which primary, secondary and interactive terms of the model equation were highly significant. Additionally, the $\mathrm{CV}$ value of this experimental design was 7.35 which reflects the confidence in the model, and the model's ability to accurately reflect real test data. Based on the response surface diagram and the contour plot of the multivariate quadratic equation, factor B (enzymatic hydrolysis time) had a significant effect on gossypol content $(p=0.02)$ and the interaction between factor $\mathrm{B}$ and 

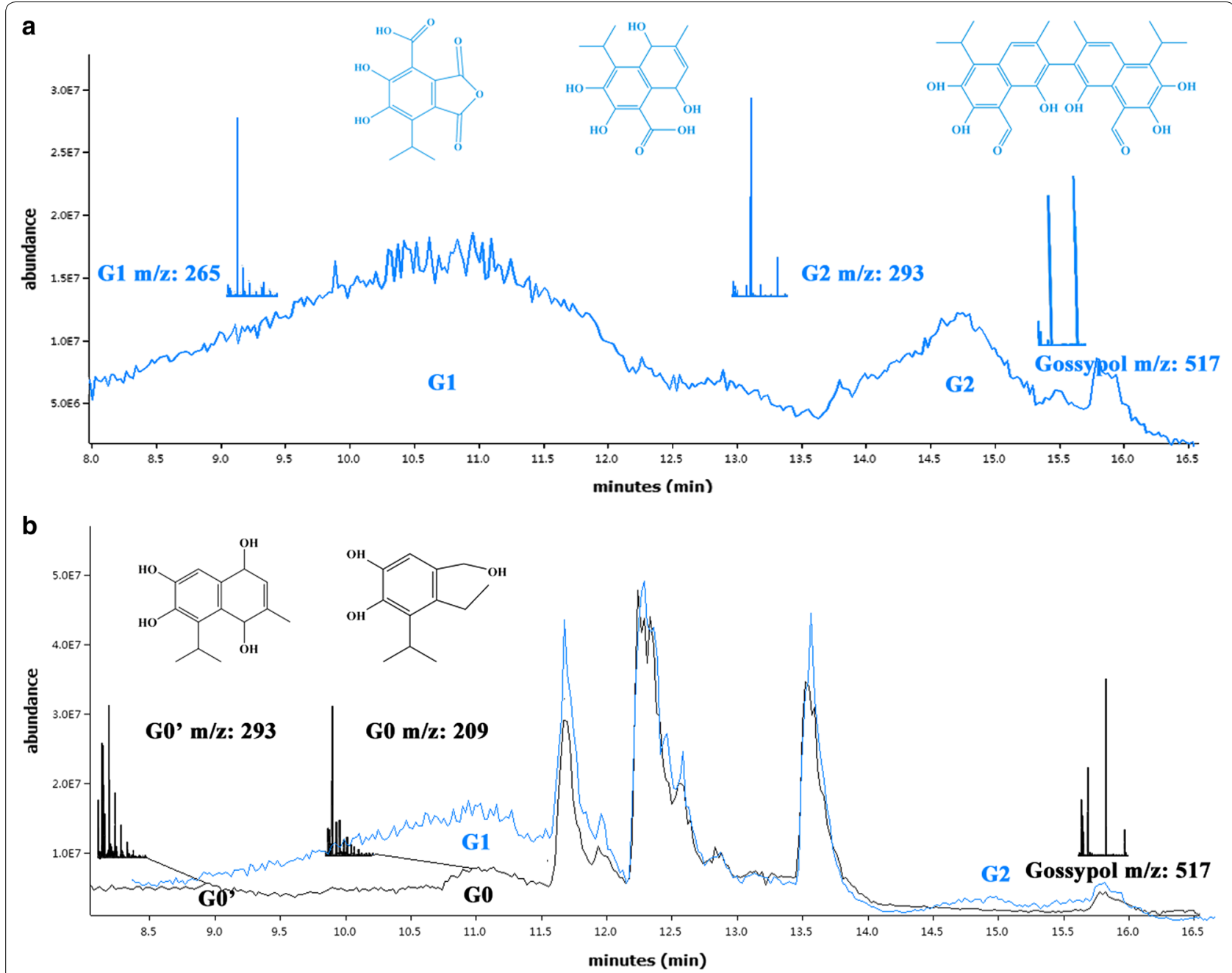

Fig. 3 Extracted LC-MS ion chromatogram of the gossypol metabolites in negative ion mode and representative mass spectra of respective of chromatograms for quantification of gossypol and metabolites. a The control group without enzyme (blue) the free gossypol spontaneously degraded to compounds G1 ( $\mathrm{m} / \mathrm{z} 265)$ and $\mathrm{G} 2(\mathrm{~m} / \mathrm{z} 293)$; $\boldsymbol{b}$ the recombinant of H. armigera CPR and CYP9A12 enzyme (black) was capable to degrade free gossypol by decarboxylation of $\mathrm{G} 1(\mathrm{~m} / \mathrm{z} 265)$ and $\mathrm{G} 2(\mathrm{~m} / \mathrm{z} 293)$ to compound G0 ( $\mathrm{m} / \mathrm{z} 209)$ and $\mathrm{G} 0^{\prime}(\mathrm{m} / \mathrm{z} 249)$. The endogenous enzyme was as shown in blue (Chen et al. 2019)

$\mathrm{D}$ (substrate moisture) $(p=0.034)$ influenced gossypol content (Fig. 2). After the predictive model and validation tests, the gossypol content could have reached a minimum of $40.91 \mathrm{mg} / \mathrm{kg}$ in CSM when the initial temperature was $35^{\circ} \mathrm{C}$; the enzymatic hydrolysis time had lasted $2.5 \mathrm{~h}$; the enzyme addition was $2.5 \mathrm{~mL}$, and the substrate moisture was $39 \%$.

At present the detoxification effect of recombinant CYP450s on cottonseed meal was still limited by the cost of the co-factor NADPH and the enzyme yield. If the enzyme could be further highly expressed by heterologous system and in industrial production which could greatly increase the rate of gossypol degradation and provide a new strategy for cottonseed meal detoxification.
The recombinant $H$. armigera CYP9A12 and its reductase were successfully expressed in the $P$. pastoris system. The CYP9A12 was able to accelerate metabolism of the gossypol intermediate metabolites. Treatment of CSM with $H$. armigera CYP9A12 enzyme significantly degraded free and total gossypol. After optimization of the single-test and response surface method, the free gossypol content could decrease to $40.91 \mathrm{mg} / \mathrm{kg}$ in the CSM when the initial temperature was $35^{\circ} \mathrm{C}$, the enzymatic hydrolysis time lasted $2.5 \mathrm{~h}$, the enzyme addition was $2.5 \mathrm{~mL}$, and the substrate moisture was $39 \%$. 


\section{Abbreviations}

GO' to G2: gossypol metabolite $0^{\prime}$ to gossypol metabolite 2; CPR: NADPHcytochrome P450-reductase; CYP9A12: cytochrome P450-monooxygenase CYP9A 12; CSM: cottonseed meal; H. armigera: Helicoverpa armigera; P. pastoris: Pichia pastoris; GA: Gibson assembly.

\section{Acknowledgements}

The authors would like to thank professor Lee J. Johnston from University of Minnesota for reviewing an early draft of this article.

\section{Authors' contributions}

WZ and WP designed research; CC, YZ and WY performed research; JL, CN and $X M$ discussed results and provided advice; $C C$ and WY analyzed data; and CC and $Y Z$ wrote the paper. All authors read and approved the final manuscript.

\section{Funding}

This study was funded by National Natural Science Foundation of China (Grant no. 31860660)

\section{Availability of data and materials}

All data generated or analyzed during this study are included in this published article.

\section{Ethics approval and consent to participate}

This article does not contain any studies with human participants or animals performed by any of the authors.

\section{Competing interests}

The authors declare that they have no competing interests.

\section{Consent for publication}

Not applicable.

\section{Author details}

${ }^{1}$ College of Animal Science and Technology, Shihezi University, Shihezi 832000, Xinjiang, China. ${ }^{2}$ School of Chemistry and Chemical Engineering, Shihezi University, Shihezi 832000 , Xinjiang, China. ${ }^{3}$ State Key Laboratory for Sheep Genetic Improvement and Healthy Production, Xinjiang Academy of Agricultural and Reclamation Sciences, Shihezi 832000, Xinjiang, China. ${ }^{4}$ State Key Laboratory of Animal Nutrition, College of Animal Science and Technology, China Agricultural University, Beijing 100193, China.

Received: 26 April 2019 Accepted: 24 June 2019

Published online: 05 July 2019

\section{References}

Abou-donia MB, Dieckert JW (1974) Urinary and biliary excretion of ${ }^{14}$ C-gossypol in swine. J Nutr 104:754-760. http://jn.nutrition.org/conte nt/104/6/754.long

Abou-Donia MB, Dieckert JW (1975) Metabolic fate of gossypol: the metabolism of ${ }^{14} \mathrm{C}$-gossypol in swine. Toxicol Appl Pharm 5:32-46

Andersen JF, Utermohlen JG, Feyereisen R (1994) Expression of house fly CYP6A1 and NADPH-cytochrome P450 reductase in Escherichia coli and reconstitution of an insecticide-metabolizing P450 system. Biochemistry 33:2171-2177

Bradford MMA (1976) A rapid and sensitive method for the quantitation on microgram quantities of protein utilizing the principle of protein-dye binding. Anal Biochem 72:248-254

Brocas C, Rivera RM, Paulalopes FF, Mcdowell LR, Calhoun MC, Staples CR, Wilkinson NS, Boning AJ, Chenoweth PJ, Hansen PJ (1997) Deleterious actions of gossypol on bovine spermatozoa, oocytes, and embryos. Biol Reprod 57:901

Celorio-Mancera ML, Ahn SJ, Vogel H, Heckel DG (2011) Transcriptional responses underlying the hormetic and detrimental effects of the plant secondary metabolite gossypol on the generalist herbivore Helicoverpa armigera. BMC Genomics 12:575. https://doi. org/10.1186/1471-2164-12-575

Chen C, Nie CX, Liang J, Wang YQ, Liu YF, Ge WX, Zhang WJ (2018) Validated method to determine $( \pm)$-gossypol in Candida tropicalis culture by high-performance liquid chromatography. Acta Chromatogr 30(4):269273. https://doi.org/10.1556/1326.2018.00420

Chen C, Pi WH, Zhang Y, Nie CX, Liang J, Ma X, Wang YQ, Ge WX, Zhang WJ (2019) Effect of a functional recombinant cytochrome P450 enzyme of Helicoverpa armigera on gossypol metabolism co-expressed with $\mathrm{NADPH}$-cytochrome P450 reductase in Pichia pastoris. Pestic Biochem Phys. https://doi.org/10.1016/j.pestbp.2019.01.003

Chenoweth PJ, Chase CC Jr, Risco CA, Larsen RE (2000) Characterization of gossypol-induced sperm abnormalities in bulls. Theriogenology 53:1193-1203. https://doi.org/10.1016/S0093-691X(00)00264-8

Dietrich M, Grundmann L, Kurr K, Valinotto L (2005) Recombinant production of human microsomal cytochrome P450 2D6 in the methylotrophic yeast Pichia pastoris. ChemBioChem 6:2014. https://doi.org/10.1002/cbic.20050 0200

Dodou K (2005) Investigations on gossypol: past and present developments. Expert Opin Invest Drugs 14:1419-1434. https://doi.org/10.1517/13543 784.14.11.1419

Donnelly ML, Hughes LE, Luke G, Mendoza H, Ten DE, Gani D, Ryan MD (2001) The 'cleavage' activities of foot-and-mouth disease virus 2A sitedirected mutants and naturally occurring '2A-like' sequences. J Gen Virol 82:1027-1041. https://doi.org/10.1099/0022-1317-82-5-1027

Eisele GR (1986) A perspective on gossypol ingestion in swine. Vet Hum Toxicol 28:118

Ferreira SLC, Bruns RE, Ferreira HS, Matos GD, David JM, Brandão GC, Silva EGP, DaPortugal LA, Reis PS, DosSouza AS (2007) Box-Behnken design: an alternative for the optimization of analytical methods. Anal Chim Acta 597(2):179-186. https://doi.org/10.1016/j.aca.2007.07.011

Firestone D (2003) Official methods and recommended practices of the AOCS, 5th edn. Champaign, AOCS

Guengerich FP, Martin MV, Sohl CD, Cheng Q (2009) Measurement of cytochrome $\mathrm{P} 450$ and NADPH-cytochrome $\mathrm{P} 450$ reductase. Nat Protoc 4(9):1245-1251. https://doi.org/10.1038/nprot.2009.121

Guzov VM, Unnithan GC, Chernogolov AA, Feyereisen R (1998) CYP12A1, a mitochondrial cytochrome P450 from the house fly. Arch Biochem Biophys 359:231-240. https://doi.org/10.1006/abbi.1998.0901

Hayashi S, Omata Y, Sakamoto H, Hara T, Noguchi M (2003) Purification and characterization of a soluble form of rat liver NADPH-cytochrome P450 reductase highly expressed in Escherichia coli. Protein Expr Purif 29:1

Jia L, Coward LC, Kerstnerwood CD, Cork RL, Gorman GS, Noker PE, Kitada S, Pellecchia M, Reed JC (2008) Comparison of pharmacokinetic and metabolic profiling among gossypol, apogossypol and apogossypol hexaacetate. Cancer Chemother Pharmacol 61:63-73

Kaewpa D, Boonsuepsakul S, Rongnoparut P (2007) Functional expression of mosquito NADPH-cytochrome P450 reductase in Escherichia coli. J Econ Entomol 100:946-953

Kong G, Daud MK, Zhu S (2010) Effects of pigment glands and gossypol on growth, development and insecticide-resistance of cotton bollworm (Heliothis armigera (Hübner)). Crop Prot 29:813-819

Krempl C, Heidel-Fischer HM, Jiménez-Alemán GH, Reichelt M, Menezes RC, Boland W, Vogel H, Heckel DG, Joußen N (2016a) Gossypol toxicity and detoxification in Helicoverpa armigera and Heliothis virescens. Insect Biochem Mol Biol 78:69-77. https://doi.org/10.1016/j.ibmb.2016.09.003

Krempl C, Sporer T, Reichelt M, Ahn S-J, Heidel-Fischer H, Vogel H, Heckel DG, Joußen N (2016b) Potential detoxification of gossypol by UDP-glycosyltransferases in the two Heliothine moth species Helicoverpa armigera and Heliothis virescens. Insect Biochem Mol Biol 71:49-57. https://doi. org/10.1016/j.ibmb.2016.02.005

Liu X, Zhang L, Zhang X, Xi WG (2012) Molecular cloning and recombinant expression of cytochrome P450 CYP6B6 from Helicoverpa armigera in Escherichia coli. Mol Biol Rep 40:1211-1217. https://doi.org/10.1007/ S11033-012-2163-1

Liu H, Sun H, Lu D, Zhang Y, Zhang X, Ma Z, Wu B (2014) Identification of glucuronidation and biliary excretion as the main mechanisms for gossypol clearance: in vivo and in vitro evidence. Xenobiotica 44:696-707. https:// doi.org/10.3109/00498254.2014.891780

Mao YB, Cai WJ, Wang JW, Hong GJ, Tao XY, Wang LJ, Huang YP, Chen XY (2007) Silencing a cotton bollworm P450 monooxygenase gene by plant-mediated RNAi impairs larval tolerance of gossypol. Nat Biotechnol 25:1307-1313. https://doi.org/10.1038/nbt1352

Mao YB, Tao XY, Xue XY, Wang LJ, Chen XY (2011) Cotton plants expressing CYP6AE14 double-stranded RNA show enhanced resistance to 
bollworms. Transgenic Res 20:665. https://doi.org/10.1007/s1124 8-010-9450-1

Matlin SA, Zhou R (1984) Resolution of gossypol: analytical and preparative HPLC. J Sep Sci 7:629-631

Matlin SA, Zhou RH, Belenguer A, Tyson RG, Brookes AN (1988) Large-scale resolution of gossypol enantiomers for biological evaluation. Contraception 37:229

Mirzaei SA, Yazdi MT, Sepehrizadeh Z (2010) Secretory expression and purification of a soluble NADH cytochrome b5 reductase enzyme from Mucor racemosus in Pichia pastoris based on codon usage adaptation. Biotechnol Lett 32:1705-1711. https://doi.org/10.1007/s10529-010-0348-z

Nomeir AA, Abou-Donia MB (1985) Toxicological effects of gossypol. In: Lobl TJ, Hafez ESE (eds) Male fertility and its regulation. Advances in reproductive health care, vol 5. Springer, Dordrecht

Pompon D, Louerat B, Bronine A, Urban P (1996) Yeast expression of animal and plant P450s in optimized redox environments. Method Enzymol 272:51-64

Stipanovic RD, Lopez JD, Dowd MK, Puckhaber LS, Duke SE (2006) Effect of racemic and (+)- and (-)-gossypol on the survival and development of Helicoverpa zea larvae. J Chem Ecol 32:959-968. https://doi. org/10.1603/0046-225X(2008)37\%5b1081:EORAGO\%5d2.0.CO;2

Tao X, Xue X, Huang Y, Chen X, Mao YB (2012) Gossypol-enhanced P450 gene pool contributes to cotton bollworm tolerance to a pyrethroid insecticide. Mol Ecol 21:4371-4385. https://doi.org/10.1111/j.1365294X.2012.05548.X

Tian K, Liu D, Yuan Y, Li M, Qiu X (2017) CYP6B6 is involved in esfenvalerate detoxification in the polyphagous lepidopteran pest, Helicoverpa armigera. Pestic Biochem Phys. https://doi.org/10.1016/j.pestbp.2017.02.006

Wei E, Zhang W, Liu D, Yu L, Shi G (2011) Effect of mixed culture fermentation on the contents of free and bound gossypol in cottonseed cake. Feed Ind 32(20):34-37 (In Chinese)

Yang WH, Li HM, Zhu HQ (1999) Effects of different enantiomers of gossypol on the growth and development of cotton bollworm and Fusarium wilt. Acta Gossypii Sinica 11(1):34-37 (In Chinese)
Yang Y, Wu Y, Chen S, Devine GJ, Denholm I, Jewess P, Moores GD (2004) The involvement of microsomal oxidases in pyrethroid resistance in Helicoverpa armigera from Asia. Insect Biochem Mol Biol 34:763-773. https://doi. org/10.1016/j.ibmb.2004.04.001

Yang Y, Yue L, Chen S, Wu Y (2008) Functional expression of Helicoverpa armigera CYP9A12 and CYP9A14 in Saccharomyces cerevisiae. Pestic Biochem Phys 92(2):101-105. https://doi.org/10.1016/j.pestbp.2008.07.001

Yildirimaksoy M, Lim C, Wan P, Klesius PH (2004) Effect of natural free gossypol and gossypol-acetic acid on growth performance and resistance of channel catfish (Ictalurus punctatus) to Edwardsiella ictaluri challenge. Aquac Nutr 10:153-165

Zhang WJ, Xu ZR, Sun JY, Yang X (2006a) Effect of selected fungi on the reduction of gossypol levels and nutritional value during solid substrate fermentation of cottonseed meal. J Zhejiang Univ Sci B 7:690-695

Zhang WJ, Xu ZR, Zhao SH, Jiang JF, Wang YB (2006b) Optimization of process parameters for reduction of gossypol levels in cottonseed meal by Candida tropicalis ZD-3 during solid substrate fermentation. Toxicon 48:221-226

Zhong YC, Wu $\sqcup$ (1989) Detoxification of gossypol in cottonseed by microorganisms. Acta Sci Nat Univ Sunyatseni 3:67-72 (In Chinese)

Zhou X, Ma C, Li M, Sheng C, Liu H, Qiu X (2010) CYP9A12 and CYP9A17 in the cotton bollworm, Helicoverpa armigera: sequence similarity, expression profile and xenobiotic response. Pest Manag Sci 66:65-73. https://doi. org/10.1002/ps.1832

\section{Publisher's Note}

Springer Nature remains neutral with regard to jurisdictional claims in published maps and institutional affiliations.

\section{Submit your manuscript to a SpringerOpen ${ }^{\circ}$ journal and benefit from:}

- Convenient online submission

- Rigorous peer review

- Open access: articles freely available online

- High visibility within the field

- Retaining the copyright to your article

Submit your next manuscript at $\boldsymbol{\nabla}$ springeropen.com 